\title{
A Comparative Cost Disadvantage Driven By Foreign Competition
}

\author{
Amaechi Nkemakolem Nwaokoro, Ph.D., Albany State University, USA
}

\begin{abstract}
This study focuses on the impact of foreign physical steel imports on the output of the US steel industry. This industry faces a comparative disadvantage in costs and from reduced utilized capacity in steel making. The strong desire of many foreign steel producers to export steel to the US lucrative market led to their plant modernization with the associated economies of scale. This led to steel import surge in America. The imposed trade restrictions had mixed outcomes. The domestic steel output is modeled as function of steel imports and from the size of the economy addressed by shipments. The OLS estimate of steel imports is insignificant and this could be explained by the ineffectiveness of the various instituted trade instruments, from increased foreign prices of steel, and from depreciated dollars at some points in time during the period in study. As expected the measure of the economy - shipments variable has a positive impact on steel production.
\end{abstract}

Keywords: trade policies, market conditions, foreign prices, trade instruments, overcapitalization, economies of scale, dumping, productivity, ${ }^{*}$ competitive edge, quotas, subsidies, capital restructuring

\section{INTRODUCTION}

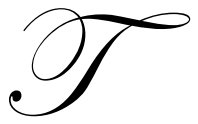

he goal of every nation is to have a favorable balance of trade. Therefore countries engage both innovativeness and trade policies as factors to achieve or enhance their favorable balance of tradeincrease exports over the respective imports. This encourages retaliatory policies among nations involved in trade. In most cases contemporary politics form the basis of the restrictive trade policies. It was a boom for the U.S. Steel industry in the periods of 1940s and 1950s. As from the 1960s through 1980s the industry witnessed unfavorable market conditions and structural problems. The structural problem started in 1950s as a result of capital expansion and without capital consolidation. A lot of utilize capacities as a result, developed.

With a substantial physical efficiency and productivity, the industry fulfilled a substantial part of the international steel demand in 1940s and 1950s. The industry therefore was able to record a renounced benefit of economies of scale in the world ${ }^{1}$. Growing import problem faced by the industry was visible in the 1960s, 1970s and 1980s. A striking period for the increasing steel imports in America was during the 1959 four-month strike. As steel consumers scramble to increase their levels of steel inventories, steel crisis developed and led to increase in demand for steel. Steel import problem has led to a strong variation in the domestic steel output in the very critical period of 1963 to 1988.

U.S. lucrative steel market motivated many nations especially the developing nations to export to the market. A big portion of the blame for the increasing imports was placed on Eisenhower Administration for upgrading the foreign steel plants where exports were increasingly sent to the United States. To the developing countries, development of steel industry was a means of generating industrial exports for engaging this market. Therefore many developing nations focused on the development of this technically and heavily integrated sector that could foster their macroeconomic development. So focusing on a heavy industry such as steel that was commanding foreign reserves was deemed a profitable venture associated with national wealth and prestige.

An incentive to send steel into this market increased during the periods of dollar appreciation. As dollar appreciated, U.S. exports became more expensive, imports became less expensive and countries exporting to 
American market were able to maximize their earnings. This study therefore wants to explore the sources and the magnitude of the steel import assault on the US steel output. With availability of data, steel imports variable will not be identified by a proxy.

To show the impact of steel imports on the domestic steel production, the domestic steel production is generally and empirically modeled as function of steel imports. Another factor, other shipment (total shipments minus steel shipments) is introduced in the model to measure the impact of the economy on domestic steel production during the wave of increasing steel imports. The estimate of steel imports is insignificant and this is explained by the net impact of the various instituted trade instruments, from increased foreign prices of steel, and from depreciated dollars at some points in time during the period in study. As expected the measure of the economy — other shipments variable has a positive impact on steel production.

The following is the remainder of the study. In section II the study revisits with the critical issues about steel imports and exports. Section III surveys the sources of US steel imports. Section IV centers discussion on the panic attitudes of steel consumers. Respectively, sections V and VI center on data, research methodology and empirical results, and conclusion. I will relate this research to Aw and Roberts (1985), MacPhee (1974), United States International Trade Commission (1988).

\section{CRITICAL ISSUES ABOUT STEEL IMPORTS AND EXPORTS}

The US steel industry witnessed a substantial physical efficiency and productivity in 1940s and 1950s, and fulfilled a substantial part the international steel demand. Generally, increasing imports is a problem in America. The most damaged domestic industry by imports has been the U.S. steel industry. It has been very much marginalized to the extent that one could say that the U.S. market could eventually depend entirely on foreign steel. Steel import crisis dominated the entire 1970s.

To enhance efficiency, Japanese adopted continuous casting technology in steel making in the 1980s. And as more of the foreign competitors adopted the newest technology in the period, the U.S. steel industry was challenged to adopt similar technologies in the midst of its vast and expanded capital base from the 1950s. The industry therefore became highly overcapitalized (Hogan, 1983, pp. 6-7, 77, 80, 108-109, Barnett \& Schorsch 1983, pp. 13, 27). The technical changes have had a devastating impact on the U.S. steel industry as the change in technology led to a substantial cost reduction in Japan and in some other countries but not in the US (1989, US International Trade Commission). The low production cost advantage from economies of scale of the foreign producers led to dumping of steel in American market. The result of all the changes in technology has led to a decline in the output of U.S. steel industry.

Before 1985 VRAs, appreciated U.S. dollars, increased costs for both raw materials and labor were claimed to be responsible for an unfavorable differential cost of production especially between US and Japanese steel producers (1989, US International Trade Commission). Also, fixed cost of production increased for the U.S. steel producers as the utilized capacity substantially decreased. These compelled integrated plants to consolidate some facilities and to retire out- of -date facilities and plants there were costly to operate. The needed raw materials were purchased from the "spot market" to avoid commitments in long term contracts and for factors prices to be sensitive to the market prices. Energy prices were equally handled favorably in contracts. The mini-mills also confronted the situation by lowering factor prices and enhancing productivity. The differential cost disadvantage was mostly checked by improvement in cost reduction from the integrated steel plants, from the efficiency of mini-mills, and from favorable change in exchange rate. As verified in the table 1 below, even with the technical and contractual adjustments, foreign steel producers still enjoyed a strong comparative advantage over the US steel plants.

The high cost of labor reflected a high union wage rate paid in the US steel industry (Nwaokoro, 2004). Labor contracts seemed to favor US steel workers. As the union created classical unemployment, productivity increased and this would therefore increase the wage rate. The cost differential percentage narrowed down from 159 in 1982 to 10 in 1988. Employer insistence on cost reduction or employees' concessions or increasing use of technology might have led to narrowing down the cost percentage gap. The gap might have narrowed as factors 
prices became sensitive to the market prices. Japanese steel labor seemed to be having favorable contracts evidenced by the fact that cost of labor has been increasing after it fell in 1984.

Japanese steel producers have a competitive edge over the US with the cost of materials. Favorable long term contracts could explain this since Japan imports most of the raw materials. As with the cost of labor, materials cost differential percent dropped from 40 in 1982 to 5 in 1988. The winding down of this percentage could be explained by raw materials being purchased from the "spot market" to avoid commitments in long term contracts.

US steel industry has favorable access to finances for funding given the close proximity to innovative US Capital Market that is capable of attracting funds from all over the world. This advantage increased from 1982 to 1988 as evidenced by the decreasing and increasing cost of financing of US and Japanese steel producers respectively. This advantage was very important for planning short- and long- term financing. This advantage might have been reinforced in later years as factors prices became sensitive to the market prices. In summary, each of these countries commanded a favorable cost advantage in one half of the selected years. As from 1982-1984, Japanese steel producers maintained a favorable cost advantage. From 1986 to 1988, American steel producers commanded a favorable cost advantage. The 1985 VRAs and contract adjustments led to this advantage.

Table 1: Comparison of Production Costs ${ }^{1}$ for Steelmakers

Selected Years 1982-1988

\begin{tabular}{cccc}
\hline Item & Japan & United States & Cost Differential $^{2}$ \\
\hline Labor & U.S. Dollars & U.S. Dollars & Percent \\
\hline 1982 & $\$ 101$ & $\$ 262$ & 159 \\
1984 & 92 & 181 & 97 \\
1986 & 132 & 167 & 10 \\
1988 & 145 & 160 & \\
Materials & & & 30 \\
1982 & 253 & 355 & 38 \\
1984 & 229 & 315 & 11 \\
1986 & 260 & 288 & 5 \\
1988 & 277 & 291 & \\
Financial & & 68 & $(30)$ \\
1982 & 98 & 60 & $(38)$ \\
1984 & 97 & 51 & $(60)$ \\
1986 & 128 & 43 & $(59)$ \\
Total & 105 & & 52 \\
1982 & & 685 & \\
1984 & 452 & 557 & $(34)$ \\
1988 & 417 & 506 & $(12)$ \\
\hline
\end{tabular}

${ }^{1}$ Per metric ton of finished steel.

${ }^{2}$ Estimated U.S. production costs as a percent of Japanese costs.

Source: U.S. International Trade Commission March 1989.

Steel import problem has led to the institution of various trade agreements including Voluntary Restrictions Agreements (VRAs) between U.S. and some other countries. In effect there are twenty VRAs that were negotiated with European community, and with 19 other countries during the period studied (US International Trade Commission, 1989). With 1985 VRAs, quotas were enforced until 1986 and it became a lax in 1987. Strong dollars or increase in demand might have led to this lax market condition. 
Austria, and Finland. The respective shares of these nations are comparable. The need to maintain strong market shares has led to these countries observing comparable shares. Foreign governments had history of providing subsidies to their steel industries and had led to the import surge in America market.

The US has many steel quota agreements with many nations including eastern European countries, developing nations, and China. These countries, especially those that are based on centrally planned economies, and developing nations needed steel exports promotions to enhance economic development. No one country controls up to one percent share of the market based on quota agreements. This implies that many nations scrambled the viable US steel market to have some level of quota. Poland enjoyed the highest percent share of the market based on these agreements.

Based on semi-finished steel agreements, EC sent the highest quota to the US market. This is closely followed by Brazil, Japan, and Mexico. The respective quotas of other countries in these agreements are comparable. This implied that nations with these contracts negotiated very hard to have comparable shares of US semi-finished steel import market.

\section{THE PANIC ATTITUDES OF STEEL CONSUMERS}

The US steel consumers are driven by steel market shocks or panics. Fearing the possibility of running out of steel inventory, the US steel consumers have a history of stockpiling inventory. For example, stockpiling inventory and economic activity led to an increase in the apparent steel consumption in the period of 1983-1988. Inventory increased by 24 percent and this reflected a significant demand in 1987-1988 (US International Trade Commission, 1989). The steel import crisis in America started as a result of the 1959 strike that lasted for four months. A panic attitude of the consumers to stockpile steel products during this long strike caused steel consumers to demand more imports.

The crisis situation caused the U.S. to become a net importer of steel for the first time. The dollar was weak in the period of 1985-1987. Therefore domestic steel output increased. In 1959, U.S. steel exports and imports were 1.5 and 4.5 million tons, respectively (Hogan 1991, p. 144). As foreign steel became cheaper than domestic steel, steel consumers' attitudes were directed to demanding imported steel which grew significantly in the 1960s. The threats of strikes in 1965 and 1968 reinforced the consumers' desire for imports which grew rapidly from 4 million tons in 1963 to 10.3 million tons in 1965 (Hogan 1991, p. 144).

An increase in the 1970 price levels of European and Japanese steel made the U.S. steel consumers to purchase more from local producers. This led to the leveling off of steel imports (Hudson \& Sadler 1989). Because the 1971 price fell in the EEC and in Japan but not in the U.S., an increase in the level of steel imports was experienced in the U.S. market. The increased imports led to a revision of the existing VRAs. Eventually, VRAs were initiated for 1972-1974, but all restrictions ended in 1973. These VRAs set the yearly U.S. steel ceilings at 7.3 and 5.9 million tons, respectively, for the steel exports from the EEC and Japan. Though a provision was made in these VRAs regarding the U.S. imports of some specialty steels like stainless, alloy, and other high grade steel products, it was not enforced.

The market was lucrative in 1973 as a result of the dollar's devaluation in 1971 and again in 1973. There was a shortage of steel. Steel import prices rose, and demand was strong in Japan and in the EEC. As the boom continued in 1974, the U.S. government did not enforce the 1969-1972 VRAs. In 1975, there was an acute drop in U.S. steel production. An incentive to advance employment in Japan and in Europe in most of the 1970s caused a jump in their steel export levels into the United States. Between 1976 and 1977, U.S. steel imports increased from 14.3 million tons to 19.3 million tons. Imports were priced below the domestic producers' prices and the foreign producers' production cost. Government ownership of steel industries and government provision of heavy subsidies to steel production in some foreign countries were partially blamed for the increased competition of steel imports (Hogan 1991). 
An appreciating dollar caused import expansion in the presence of the low growth of the U.S. steel market in 1981, and by January, 1982, U.S. producers asked for countervailing duties on imports, mostly from Europe (Barnett \& Schorsch 1983, pp. 241-242). This action was initiated to stop foreign exporters from dumping steel in American market and this eventually led to the complete removal of policy regime (1978-1982) of Trigger Price Mechanism (TPM) that set steel competitive price based on Japan's steel production costs and provided 8\% profit (Barnett \& Schorsch 1983, pp. 239-240, Barnett \& Schorsch 1983, pp. 241-242)..

\section{DATA, RESEARCH METHODOLOGY, AND EMPIRICAL RESULTS}

This study employed data of annual variables for steel mill production (SIC 3312) and steel imports, and are measured in net tons ${ }^{2}$. Respectively, the means and the associated standard deviations of the series are 117,703,310 and 18,205,227 for output, 0.13 and 0.04 for steel import shares, and 19,531.24 and 2,221.11 for other shipments variable. Figure lindicates that steel imports' share in the domestic steel market, shows a general upward trend through 1985, though considerable volatility is present.

Figure 1: Steel Import Shares

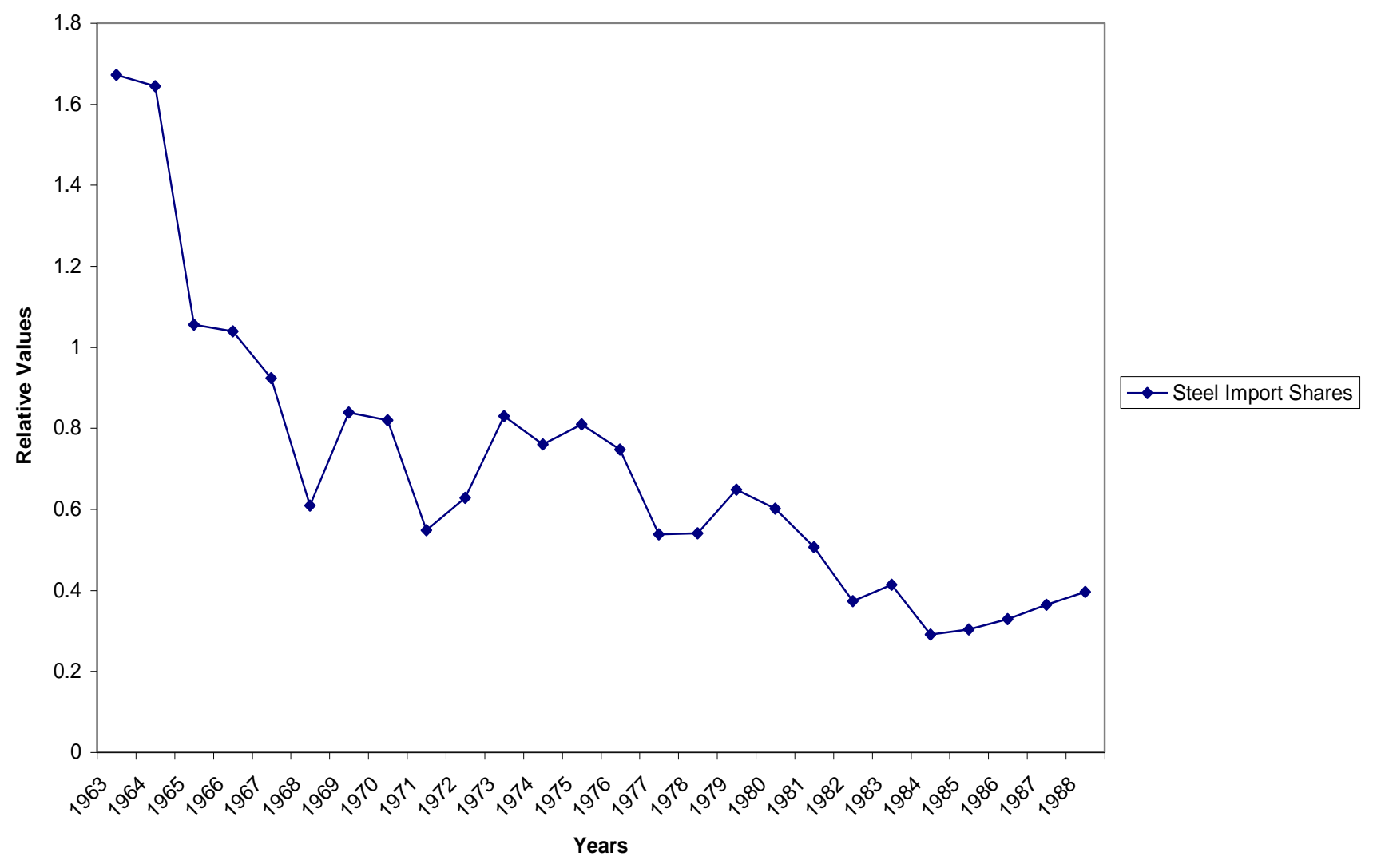

This variable declines markedly in the periods of 1971-1973 and 1985-1987. The decline of this variable in 1971-1973 is explained by the devaluation of the dollar in 1971 and 1973 and by the strong steel demand in Japan and the EEC during this period (Hudson \& Sadler, 1989; p. 49, Hogan 1991, p. 45). For the 1985-1987 periods, the decline in imports was a result of the 1985 VRAs (Hogan 1991, pp. 145-146). During the period studied, the average annual growth of steel imports between 1963 and 1975 was 9.97\% and between 1976 and 1988, this growth was $6.29 \%$. These rapid growth rates motivated the imposition of the trade restrictions. 
Less steel output fluctuation occurred in the 1960s. Domestic steel output was over 141 million tons in 1969 and was roughly 110 million tons in 1963. 1970s witnessed substantial output variations and 1980s recorded the lowest levels of steel output. By 1982 the lowest yearly steel production was below 80 million tons and this contrasts the 1981output demand level that was over 120 million tons. The steel output demand started to rose gradually in 1986 after observing fewer variations in the years following 1982. In the period of 1974 and 1985, the output of both the integrated producers and the specialty steel firms declined significantly from 102 million tons to 58 million tons (Crandall 1986, pp. 13-14). With innovational and flexible techniques, the output of mini-mills rose from about 8 million tons to 15 million tons in this same period. This highlights both integrated producers and the specialty steel firms as the firms in the industry that are affected by the steel imports surge in America. The average annual growth rate in steel production between 1963 and 1975 was $1.05 \%$. This growth rate dropped to $-0.04 \%$ between 1976 and 1988.

The other shipments variable is constructed by removing the annual steel shipments from the total U.S. manufacturing shipments. This variable is measured in millions of dollars and is a proxy for steel demand. This factor measures the impact of the economy on steel output, and is deflated with the industrial price index ${ }^{3}$.

Research Methodology: Generally, the domestic cost minimizing steel output (Q) is modeled as function of steel imports (M) and of other shipments variable (Os) as:

$Q=f(M, O s)$.

Given equation 1, the output empirical equation is stated as:

$\log Q_{t}=\alpha+\alpha_{l} \log M_{t}+\alpha_{2} \log O s_{t}+\mu_{t}$

where $\alpha_{\mathrm{i}}, \mathrm{i}=0, . ., 2$. , and $u_{\mathrm{t}}$ is the error term.

To reduce the serial correlation problem that is prevalent in a time series data, equation 2 is redefined in a difference model where any change of the variables is defined by $\dot{X}=\frac{d \log X}{d t}$. The results from equation 2 are posted in table 3.

Though columns 1-3 have the expected negative sign on the estimates of steel imports estimates, the estimates are insignificant and are statistically consistent. Serial correlation in the data is controlled in the presence of the lag of steel output and in a difference model. In the difference model, the estimate of the other shipment variable is significant indicating that the stochastic economy had a net positive impact on the steel output. As usually the case the effect of the lag of the output dominates in model. This basically implies that the current output reflected the previous output. The insignificance of the estimate of the steel imports could be explained by the netpositive effects of the various instituted VRAs and other trade agreements, from increased foreign prices of steel, and from devalued dollars at some points in time during the period in study.

Fearing the possibility of running out of steel inventory, the US steel consumers have a history of stockpiling inventory. For example, stockpiling inventory and economic activity led to an increase in the apparent steel consumption in the period of 1983-1988. Inventory increased by 24 percent and this reflected a significant demand in 1987-1988 (US International Trade Commission, 1989). The steel import crisis in America started as a result of the 1959 strike that lasted for four months. A panic attitude of the consumers to stockpile steel products during this long strike caused steel consumers to demand more imports. 


\begin{tabular}{|c|c|c|c|c|}
\hline & $\begin{array}{c}1 \\
\text { OLS Basic Mode } \\
\text { with M }\end{array}$ & $\begin{array}{c}2 \\
\text { OLS Basic Mode } \\
\text { with M, Os }\end{array}$ & $\begin{array}{c}3 \\
\text { OLS Basic Model } \\
\text { with Lagged Q }\end{array}$ & $\begin{array}{c}4 \\
\text { OLS Diff Model }\end{array}$ \\
\hline \multicolumn{5}{|l|}{ Explanatory Variable } \\
\hline Constant Term & $\begin{array}{c}18.95^{*} \\
(1.73)\end{array}$ & $\begin{array}{c}20.43^{*} \\
(2.81)\end{array}$ & $\begin{array}{c}5.66 \\
(4.25)\end{array}$ & $\begin{array}{l}-0.05^{*} \\
(0.02)\end{array}$ \\
\hline $\mathrm{M}$ & $\begin{array}{l}-0.17 \\
(0.10)\end{array}$ & $\begin{array}{l}-0.03 \\
(0.23)\end{array}$ & $\begin{array}{l}-0.11 \\
(0.18)\end{array}$ & $\begin{array}{c}0.02 \\
(0.12)\end{array}$ \\
\hline Os & & $\begin{array}{l}-0.38 \\
(0.57)\end{array}$ & $\begin{array}{c}0.07 \\
(0.42)\end{array}$ & $\begin{array}{l}1.81^{*} \\
(0.50)\end{array}$ \\
\hline Lag Q & & & $\begin{array}{l}0.72 * \\
(0.16)\end{array}$ & \\
\hline$\overline{\mathrm{R}}^{2}$ & 0.07 & 0.04 & 0.53 & 0.40 \\
\hline DW & 0.68 & 0.68 & 2.21 & 2.68 \\
\hline Rho & 0.63 & 0.63 & -0.02 & -0.37 \\
\hline Sample size & 26 & 26 & 25 & 25 \\
\hline
\end{tabular}

*Denotes estimates that are statistically significant at the marginal probability $(\mathrm{P}=0.05)$ level.

\section{CONCLUSION}

U.S. steel output is being displaced by steel imports since 1960s. This contrasts the period of 1940s and 1950s when it was a boom for the industry. Costs rose in the industry due to overcapitalization and high cost of labor inputs. Along with these was comparative costs advantage from foreign competitors. The output of the industry therefore declined as the surge of foreign steel increased. The American steel consumers contributed to the imports surge by stockpiling in responding to domestic shocks, changes in foreign steel prices, and variation of the dollar. Eroding steel output was checked by instituting multiple VRAs and other trade agreements. Also, the industry initiated costs reduction measures by purchasing inputs from spot markets and by having contracts adjustments.

The overall impacts of the trade instruments did seem to have protected the industry after a substantial damage of steel output downward variation. The initiated costs reduction measures and contracts adjustments have had impact in boosting the competitiveness of the industry. Empirical results suggest that steel imports variable is not significant to explain domestic steel output. This implies that the imposed trade restrictions did have some appreciable impacts in restricting foreign steel. The economy had a net positive effect on steel output during the period studied. The vision of the U.S. steel industry would therefore focus on a continuous implementation of the initiated costs reduction measures and contracts adjustments. Capital restructuring has to target the reduction of excess capacities. These could enhance the competitiveness of the industry.

\section{AUTHOR INFORMATION}

Dr. Amaechi N. Nwaokoro is an Assistant Professor of Economics at Albany State University, Albany, Georgia. He earned a doctorate in economics from University of Oklahoma, a Masters of Business Administration from Oklahoma City University, and a bachelor degree in Business \& Economics from Northwestern Oklahoma State University. Dr. Nwaokoro has published half- a- dozen refereed journal articles and some conference proceedings. $\mathrm{He}$ is currently researching and writing manuscripts for publication. He has over eleven years of continuous teaching experience at both undergraduate and graduate levels of economic education.

As a member of Southwestern Social Science Association, I review articles for Southwestern Journal of Economics, an affiliate of the Association. I have made various professional presentations during the meetings of this association. Economics is my passion and I also enjoy traveling. I derive joy doing charity work. This is another call that also requires my time here on earth. 
For more details about my background, research interests, publications, and work experience request for my full resume.

Dr. Nwaokoro can be reached at 229-430-4723 or e-mail: Amaechi.nwaokoro@asurams.edu

\section{Endnotes}

${ }^{1}$ See Hogan (1991) and Barnett \& Schorsch (1983) for discussions of these issues.

${ }^{2}$ The source of this variable is Metal Statistics 1969, 1974, 1979, 1984 and 1990 series.

${ }^{3}$ Information on both the total shipments and on the steel shipments comes from the 1958-1977, 1977-1982, 1982-

1900 Current Industrial Report series, U.S. Department of Commerce.

\section{REFERENCES}

1. American Metal Market 1969, 1974, 1979, 1984 and 1990. Metal Statistics. American Metal Market. New York.

2. Aw, Bee Yan, and Mark J. Roberts. 1985. "The Role of Imports from the Newly-Industrializing Countries in U.S. Production". The Review of Economics and Statistics, 67: 108-117.

3. Barnett, Donald F., and Louis Schorsch. 1983. Steel: Upheaval in a Basic Industry. Ballinger Publishing Company. Cambridge, Massachusetts.

4. Crandall, Barnett. 1986. Up From the Ashes: The Rise of the Steel Minimill in the United States. The Brookings Institution. Washington D.C.

5. Hamermesh, Daniel. 1993. Labor Demand. Princeton University Press. Princeton.

6. Hogan, William T. 1991. Global Steel in the 1990s: Growth or Decline. Lexington Books, D.C. Heath and Company. Lexington, Massachusetts.

7. Hudson, Ray, and David Sadler. 1989. The International Steel Industry: Restructuring, State Policies and Localities. Routledge. London.

8. MacPhee, Craig R. 1974. Restrictions on International Trade in Steel. Lexington Books, D.C. Heath and Company. Lexington, Massachusetts.

9. Nwaokoro, Amaechi. 2004. "Translog Model of Employment Substitution and Economics of Scale in the U.S. Steel Industry ". The Journal of Applied Business Research, 20: 65-71.

10. SAS/ETS. User's Guide, Version 6, 2nd edition. SAS Institute Inc., Cary, North Carolina.

11. U.S. Department of Commerce: Bureau of the Census 1958-1977, 1977-1982 and 1982-1990. Current Industrial Reports: Manufacturers' Shipments, Inventories and Orders. U.S. Department of Commerce: Bureau of the Census. Washington, D.C.

12. United States International Trade Commission. 1988. U.S. Global Competitiveness: Steel Sheet and Strip Industry. United States International Trade Commission. Washington, D.C. 
International Business \& Economics Research Journal - July 2009 Volume 8, Number 7

NOTES 